Article

\title{
Dynamics in the Field of Museums: Contemporary Challenges for Polish Museologists
}

\author{
Elżbieta Nieroba \\ Institute of Sociology, University of Opole, Katowicka 89, 45-061 Opole, Poland; panagia@poczta.fm
}

Received: 14 April 2018; Accepted: 2 May 2018; Published: 4 May 2018

\begin{abstract}
The aim of this text is to present and analyze the attitudes of Polish museologists towards the changes currently taking place in the field of museums. More specifically, it will focus on their opinions regarding the evolution of museums-from the traditional model, based on symbolic violence, to the contemporary model, which accents the subjectivity of the audience. Its conclusions, based on analyses of 26 qualitative interviews with employees of Polish museums, are as follows: the organizational changes taking place in Polish museums do not relieve museologists from bureaucratic work; the collections in museums distinguish them from other institutions of culture; there is a struggle for symbolic advantage among actors in the field of museology; museologists do not know their audience well. The interviews also revealed that the assumptions of the New Museology have less impact on practice than is suggested in literature, and that everyday museology combines elements of the 'old' and 'new' philosophies.
\end{abstract}

Keywords: museum; New Museology; field of museums; cultural institution

\section{Introduction}

In the 18th century, the standard functioning of museums was called into question. At the same time, modern museums began to appear. French architect and aesthetician Quatremere de Quincy, who witnessed the building of the Louvre collection, referred to the uprooting of works from their natural environment as "cultural vandalism", and compared museums themselves to mausoleums (Witcomb 2003, p. 8). The metaphor of the mausoleum as a tomb or graveyard of works of art has been associated with criticisms from both artists and philosophers, such as futurists, Dadaists, surrealists, Valéry (2005); Adorno (2005); and Bauman (2010). Consideration of the function of the museum in a wider sociocultural context has opened up a dialog on its relations with official authorities (Duncan and Wallach 1980; Duncan 2006), its legitimization of high culture (Bourdieu et al. 1991; Bourdieu 1996; DiMaggio 1986), and its role as a venue for the production of knowledge, truth, rationality, and social discipline (Hooper-Greenhill 2003). While this dialog has mainly focused on art museums, it has significantly developed the discourse on the role museums in general, thus again raising John Cotton Dana's key question from 1917: does the world need museums (Dana 1917, p. 29)?

Constant undermining of the importance of museums, criticism of their activities, and changing public expectations have had clear effects on how museums and their employees operate. One of these effects is the development of the New Museology concept. My aim is to analyze the attitudes of museologists towards the changes taking place in the field of museums, in an effort to determine both how ready they are to transition from the traditional museum model to that which focuses more on building relations between museums and their audiences, and the extent to which the foundations of 
the New Museology impact the everyday practices of museums. My conclusions are based on analyses of 26 qualitative interviews with employees of Polish museums. ${ }^{1}$

\section{A Response to the Challenges of Modern Times: Evolution of the Museum}

The essential changes that have taken place in museums in recent decades are a result of the continuous transformation of the socio-cultural context in which they operate. Museum-goers, societies previously marginalized from museology discourses, political actors, funders of museum activities, and artists who want to be part of exhibition spaces now have different expectations regarding what a museum should be. The 18th-century modern museum model cultivated a myth of rational progress, and put a spatial and intellectual distance between the viewer and the exhibition. This traditional museum model is compliant with Pierre Bourdieu's theory of reproduction of cultural domination (Bourdieu 1996). According to this approach, museums are responsible for producing and reproducing social differences by validating the so-called legitimate culture. However, social changes have forced a reconsideration of this model among museologists. This reconsideration has led to the idea behind the New Museology—a term taken from a collected work edited by Peter Vergo in 1989. As stated by Shelley Ruth Butler (2015, p. 159), other works that reflect the essence of the idea include "Museums, the Public, and Anthropology" by Michael M. Ames (1986), and "Exhibiting Cultures: The Poetics and Politics of Museum Display", edited by Karp and Lavine (1991). These publications contained critical analyses of the status of museums in civil society. Above all, they emphasized that museums played down social contexts in favor of displaying works as stand-alone pieces (Weil 2007, p. 32; Vergo 2006, pp. 3-4). The concept of the New Museology, on the other hand, advocates the subjectivity of the audience, the necessity of contextual interpretation, and the relationship between museum activities and things like commerce and entertainment (Macdonald 2006, p. 2). These sentiments have been reflected in official decisions of The International Council of Museums (ICOM). As early as the 1970s, the "traditional concept of the museum"-i.e., as an institution limited to collecting, preserving, and displaying - was discarded in favor of that which views the museum as an institution intended to serve the development of society (Weil 2007, pp. 34-35).

The modern model of the museum was based on a universal presentation of art and the history of its audience, treated as a homogenous group. Today, however, museums are trying to cater to the expectations of a very diverse audience. In practice, this means that each museum must choose the strategy and tools appropriate for democratizing its own space (factors for consideration should include the specificity of its collection, the venue itself and the scope of its activity, its audience, its finances, its history, and its time of operation). For example, as a result of post-colonial criticism, ethnographic museums began to open up to local communities and their interpretations of heritage in order to strengthen indigenous cultural identity. They gave indigenous persons the right to self-determination in the management of their material and immaterial heritage. In multicultural environments, museums carry out projects involving cultural minorities. The purpose of these projects is to combat social exclusion and integrate various social groups in an effort to strengthen social capital (Santos dos 2008, p. 51).

The key to the success of this new museum policy is to increase the comfort of visitors, which is why changes are also taking place in exhibition spaces. These spaces are now organized to facilitate rest and relaxation (e.g., places to sit, coffee shops, book shops, souvenir shops, etc.). Furthermore, the way that museums communicate with the public has also changed. In the past, visitors were merely passive recipients of information, whereas today, they are partners in a dialog. Public relations are also upkept via participatory projects (Simon 2010), which more and more often engage visitors both physically

1 This article is an extension of the book Pomiędzy dobrem wspólnym a elitarnościa. Wspótczesny model muzeum, Opole 2016 (Nieroba 2016). 
and emotionally. The purpose of such educational measures is not only to convey facts, but to change attitudes, beliefs, and emotions (Dierking 2002, p. 5).

\section{Methodology}

The topic of this study is the field of museums and the various actors therein. These actors compete for a symbolic advantage over one another, which gives them the opportunity to monopolize the legitimacy of and standards for museum operation (Bourdieu 1995, pp. 224-25; Bourdieu and Wacquant 1992, pp. 98-100).

My aim is to analyze the extent to which Polish museologists have internalized the idea behind the New Museology, and whether or not they are ready to put its principles into practice. The research questions were as follows: What are the attitudes of museologists towards the changes taking place in the organizational structure of museums? What status does the collection have in today's museums? How do actors in the field of museology relate to one another? What status does the audience have in today's museums?

I assumed that the attitudes of the actors towards the aforementioned changes would depend on their experience, ${ }^{2}$ as well as the profile of the museums where they worked. ${ }^{3}$ This affected how I determined the research sample. First of all, in each museum, I interviewed a manager and a museologist without managerial responsibilities. They were responsible for museum content, as interviewing employees with other responsibilities (e.g., in the marketing department) could have distorted the results. Second of all, I analyzed three different types of museums: national museums, history museums, and museums of contemporary art. Within each category, I chose museums that varied according to the following characteristics: managing entity, ${ }^{4}$ location (i.e., in large provincial cities or less populated areas), and duration of operation (i.e., with long traditions or established in the 21st century). I assumed that these characteristics would impact how and to what extent they could adapt to the changing socio-cultural circumstances.

The analysis was based on empirical data collected from 13 Polish museums. The empirical material was obtained through semi-structured interviews. The technique gives access to objective meanings generated by individuals' actions. The interviews were audio-recorded and transcribed. The interview transcriptions were submitted to qualitative content analysis (I used Atlas.it to organize and code the data). The empirical material is analyzed with use of the Objective Hermeneutics Method. Ulrich Oevermann, the methodology's founder, assumes every action performed by an individual to constitute a choice made from a range of objective, socially established possibilities, each denoting a different meaning. In other words, upon every interaction, a participant of a social practice makes subjective choices based on rules they are not necessarily aware of, with the objective structure of meaning arising from these decisions. Individuals situated in a given social-historical context, operating in a set of similar circumstances, such as the employees of Polish museums, will ascribe similar meanings to their choices (Urbaniak-Zajac 2013a; Flick 2009; Reichertz 2004). Analysis resorting to the assumptions of the Objective Hermeneutics Method is aimed at the reconstruction of phenomena and processes in the social dimension, as, according to Oevermann's assumption "individual statements ( ... ) contain supra-individual, socially shared experiences" (Urbaniak-Zając 2013b, p. 226).

\section{Changes in the Field of Museology: Findings and Discussion}

The profession of curator-a professional caretaker of museum collections-appeared at the end of the 19th century. From the very beginning, definition of this profession was closely tied to

2 I use the term 'museologist' to describe all respondents. Unless necessary, I do not distinguish between museologists and curators.

3 Only public museums were analyzed.

4 Ministry of Culture and National Heritage, local governments, local government and state institutions, and legal persons. 
external expectations (Norton-Westbrook 2015; Zolberg 2004). Discussions on the direction in which the profession should develop, as well as on how to train future curators, were carried out at the beginning of the 20th century during cyclical meetings of the British Museums Association and the American Association of Museums (established in 1889 and 1906, respectively). However, before professional standards were determined, the position of curator was defined very generally. The assumptions of the day dictated that curators should be courteous, tactful, honest, and passionate about art. Moreover, they were expected to possess extensive knowledge in many fields of study (e.g., history and geography), as well as managerial skills (Norton-Westbrook 2015, pp. 344-45). In pursuit of the high prestige of European education, many future employees of American museums even studied abroad (Zolberg 2004, p. 198). Indeed, the first courses for museum workers were offered by The École du Louvre in Paris beginning in the 1870s (Boylan 2006, p. 424).

It is worth mentioning here that in the Polish tradition, there is no such term as kurator (curator), but rather kustosz or muzealnik (keeper or museologist, respectively); and that only in 1996 were museologists recognized as a group of professionals by Article 32 of the Museum Act. Two years later, the Polish Association of Museum Professionals was established, which defined the ethos of a museologist as "a universal museologist who can take inventory of science and nature, make reasoned inquiry, produce an exhibition of works, and compile a catalog" (Szukalska-Kuś et al. n.d., p. 34).

The standardization of curatorial practices in western museology focused on the collection itself, i.e., accumulation, classification, and conservation of artifacts and exhibitions. Moreover, curators of art museums were expected to be educated in art history, and universities gradually began to instate dedicated museology programs. The effect of such professionalization was a growing awareness of what a curator is-a highly qualified expert with a specialized academic degree. Over time, curators focused more and more attention on their audience and public services (Norton-Westbrook 2015, pp. 345-46). The field of museums underwent a great structural change, as reflected in the findings of the 1950 ICOM conference in London, and the 1953 ICOM conference in Milan. Due to the challenges faced by museums at the time, it was agreed that two new positions must be introduced: conservator and educator. This transformation of the organizational structure of museums was meant to enable effective implementation of the new social aims (Boylan 2006, p. 419). This involved redefining the role of the curator, as well as redistributing the tasks heretofore concentrated within a small group of professionals among wider array of actors. The curator thus ceased to play a dominant role in the museum (Norton-Westbrook 2015, pp. 346-47). In literature, we can find examples of complicated relations between museologists and educators (Zolberg 1994; Batko and Kotowski 2010, p. 55; Kowalczyk 2010; Szelag 2012; McCall and Gray 2014).

This professionalization of museum work is also visible in Poland. All the museums I examined had special departments for education, and there was clear tension between actors therein and other actors in the field. Indeed, the education departments worked with other departments, but not always harmoniously. The general reason for this is competition between museologists and educators. Furthermore, some museologists devalue the work of educators who are not formally educated in the field. Each group understands the purpose of exhibitions differently. Museologists see them as the culmination of scientific research (Borusiewicz 2012, p. 137), and educators see them as a means to communicate knowledge to the public. However, all respondents admitted that they did not acquire teaching competencies during their university studies, which would be very helpful in developing educational materials and strengthening relations with the public. Even in museums where cooperation was friendly and teamwork-based, both sides had to compromise for the sake of good relations. The interviewees also emphasized that the personality traits of individuals had a large impact on cooperation.

However, creation of new positions in the organizational structure of the museum does not mean that museologists can devote more time to their collections. On the contrary, the interviewees noted that their everyday work was inhibited above all by extensive bureaucracy, and stated that administrative work often took precedence over work with actual museum content. For most museologists, having to 
fulfill such additional duties is the norm, especially if they are employed in smaller museums without an extensive organizational structure. The research revealed that museologists are held responsible for compiling collections, building social trust (e.g., by being responsible for protecting cultural heritage and collective social memory), and being able to function as more than just art historians. In the opinion of the interviewees, this is what makes a professional museologist.

This situation is not unique to museums in Poland. Museologists all over the world claim to be overloaded with duties that go beyond actual work with collections. Researchers and theorists indicate that expansion of museologists' duties are a result of the wide spectrum of changes undergone by museums in recent decades. The most important of these changes is the status of the collection. Until recently, it was a constitutive part of the museum, but today, it seems to be losing its key importance (Kreps 2003, p. 312; McCall and Gray 2014, p. 26).

The interviewees agreed that the collections were a distinct feature of their museums. This means that museums can-and maybe even should — respond to modern challenges and adapt to global trends, but not so much as to threaten the fundamental character of the collection. These opinions are reflected in the Program of the Polish Association of Museum Professionals, which states that "our admiration for objects of heritage is the reason for the existence of museums and museologists. It is the collections of such objects that distinguish museums from other institutions of culture" (Szukalska-Kuś et al. n.d., p. 36). The responses of the interviewees regarding museum collections were somewhat inconsistent. On one hand, they referred to the items comprising museum collections as "national goods", "cultural goods", and "artistic treasures", and believed that a museum's narrative is only credible if based on original objects. On the other hand, they emphasized that the protection of objects of artistic or historical value significantly burdens museum budgets, and requires a lot of work from qualified specialists. Nevertheless, these ambivalent attitudes did not appear to prevent the respondents from making the compilation and preservation of their collections a priority among the duties imposed by the Museum Act of 1996 (Journal of Laws 2018).

In the field of museums in Poland, there is a struggle for symbolic advantage. Most active in this struggle are representatives of contemporary art museums, who build their identity among museologists through negation. In the interviews, they emphasized the specificity of their professional duties, which often go beyond that of a museologists (as defined in the Act), as they are responsible for organizing exhibitions from start to finish (invitation of artists to collaborate, setting the theme of exhibitions, obtaining funding, and design of exhibition space). The discourse on the dichotomy between the traditional and contemporary definitions of a museologist (the latter with more expansive duties), which reproduce mechanisms of exclusion, is taking place on a global level (Norton-Westbrook 2015; Fowle 2007; Kreps 2003; Marincola 2002). This dichotomy is blurred by researchers and theorists who assume that the work of museologists is a social practice. From this point of view, there is no cognitive value in maintaining a division between activities focused on the collection itself and those focused the audience, as artifacts only take on meaning in relation to people. In other words, the artistic or historical potential of a collection only develops when its value is confirmed socially, and the process of assigning meaning to objects always occurs in the context of specific socio-cultural conditions. These circumstances play a significant role in determining the nature of museologists' activities, which means that how they work with their collections is a social construct, and thus a cultural artifact. This clearly shows that change is inherent to museological practices, just like to all other social practices.

The research for this work revealed two attitudes towards the changes taking place in the field of museums: defensive and offensive. These attitudes correspond to the above dichotomy between the more traditional approach to museology, and the more contemporary approach, which views museological work in a wider social context. The research sample was divided nearly in half, with a slight majority of defensive attitudes. The museologists with defensive attitudes could be divided into conservatives (mostly without managerial responsibilities) and pragmatic conservatives. The museologists with offensive attitudes could be divided into benevolent observers (generally 
with extensive experience) and reflective reformers (mostly museum managers). A basic distinction between these categories is their attitude towards the public, i.e., whether they see the public as an active participant in culture, or a passive recipient of museum information.

Conservatives see the museum as a 'noble' institution, and therefore require from the public an awareness that they are entering a temple of art. This means that the museum is not an institution for everyone, but for those in possession of sufficient cultural capital. Conservatives emphasize that the need for art and culture should be cultivated from an early age, as the value systems adopted during childhood also guide us as adults. Pragmatic conservatives have a similar view. They see the museum as an institution that sets the standards for participation in culture, and emphasize that the public is not ready to experience exhibitions without guidance. Nevertheless, they want to maintain control over individuals through the new tools that have spurred changes in museology (e.g., new technologies). By using new techniques of discipline aimed at increasing the pleasure of museum-goers, they build spaces that therefore seem democratic, but which actually still establish social and cultural distinctions (Hooper-Greenhill 2003, pp. 198, 214).

The defensive respondents appeared to view the public as an object to be shaped. They share a sense of an enlightened mission to educate the public in the spirit of P. Bourdieu's symbolic violence. The defensive attitude of conservatives and pragmatic conservatives can be attributed to a fear of losing authority. Fulfillment of the expectations of contemporary society towards museums would deprive them of all the tools they have used to establish their privileged position. The benevolent observers and reflective reformers have a different attitude towards the public. Generally speaking, they treat the museum as a friendly space for building relations between individuals. Ensuring the comfort of visitors is just as important to them as caring for their collections. They do not judge the public in terms of cultural capital, but instead try to understand them and treat them as partners. The reflexive reformers in particular declared that museums should divide their efforts equally between satisfying the expectations of the public and taking care of their collections. They are trying to resolve the conflict between elitism and simple entertainment by working out a model that combines the traditional, object-centered approach with more innovative practices intended to engage the public.

\section{Conclusions}

Museums are facing many challenges today. They are trying to attract the attention of a diverse audience, gain an advantage over their competition, and meet the expectations of their financers. The struggles facing Polish museums are not specific to our times. As shown by Andrea Witcomb, museums have been operating with a view to consumerism, media, and tourism since the 19th century. The current transformation of museums into institutions of relaxation is therefore harmonizing with 19th-century practices (Witcomb 2003, p. 18). However, the following question remains: to what extent do these changes mean real democratization of the museum space? The interviews indicated that for many Polish museologists, it is important that the museum maintain its dominant position in contemporary society. This view is in line with that of P. Bourdieu, according to which institutions of culture construct and reconstruct the social order, leaving little space for any direct influence from the public. All respondents admitted to not knowing their audience very well. Their opinions on the needs of their audiences were based on their own informal observations or what they see in the media. The majority of museologists see their audience as a homogenous group. They consider the public in general categories-i.e., either sensitive or uneducated - which help reproduce mechanisms of exclusion from the field of culture.

The attitudes of the respondents in this study are not exceptional in the field of museology. For example, research indicates that art museums have a major problem opening up to the needs and expectations of the public. Among others, this was shown by Ien Ang, who analyzed the democratization of access to art in two Australian museums: The Art Gallery of New South Wales and The Museum of Contemporary Art. She believes that there are certain ideological boundaries that museum workers cannot or do not want to cross, lest their museums lose their distinctive features. 
They operate within the view that art is a tool for symbolic violence and validation of the dominant culture. Of course, there are many practices without which contemporary museums are unable to function, such as education programs, interactive projects, and layout rearrangement (e.g., by installing cafes), but these activities do not have to fundamentally change the philosophy behind their operation. A visit to the museum is still an intellectual experience, and not just simple entertainment. The 'raison d'être' of these museums is aesthetic, and a 'belief in art' is fundamental to the professional identity of a museologist. A change in this approach would be tantamount to the end of the museum as we now know it (Ang 2015).

The respondents, who represented various types of museums, had two general attitudes towards the changes taking place in the field of museology: defensive (conservatives and pragmatic conservatives), and offensive (benevolent observers and reflective reformers). Regardless of which attitude individual respondents had, they all combined elements of the new and old philosophies of museum operation in their everyday practices. As the research has shown, the rhetoric of the New Museology has far less impact on museum practices than literature would suggest. Museums are too complex a social organism to fit so neatly into the theoretical framework presented in literature (Ang 2015; McCall and Gray 2014). The various types of museums and the attitudes of their workers towards democratization of museum space has given rise to a new perspective on the museum as an institution of culture. Theoreticians are moving away from the concept of the 'museum' as an abstract, singular entity to a perspective that underlines their heterogenous nature (Ang 2015, p. 211). Nevertheless, there is no doubt that the New Museology is a useful signpost for museums trying to redefine their place in the world.

Conflicts of Interest: The author declare no conflict of interest.

\section{References}

Adorno, Theodor W. 2005. Muzeum Valéry Proust. In Muzeum sztuki. Antologia. Edited by Maria Popczyk. Kraków: Universitas, pp. 91-104.

Ames, Michael M. 1986. Museums, the Public, and Anthropology. A Study in the Antrophology of Antrophology. Vancouver: University of British Columbia Press, New Dehli: Concept Publishing Company.

Ang, Ien. 2015. Change and Continuity. Art Museums and the Reproduction of Art-Museumness. In The International Handbooks of Museum Studies: Museum Theory, 1st ed. Edited by Andrea Witcomb and Kelly Message. Chichester: Wiley/Blackwell, pp. 211-31.

Batko, Roman, and Robert Kotowski. 2010. Nowoczesne Muzeum. Dziedzictwo i Wspótczesność. Kielce: Muzeum Narodowe w Kielcach.

Bauman, Zygmunt. 2010. Między Chwila a Pięknem. O Sztuce w Rozpędzonym Świecie. Łódź: Wydawnictwo Officyna. Borusiewicz, Mirosław. 2012. Nauka czy Rozrywka? Nowa Muzeologia w Europejskich Definicjach Muzeum. Kraków: Universitas.

Bourdieu, Pierre, and Loïc Wacquant. 1992. An Invitation to Reflexive Sociology. Chicago: The University of Chicago Press. Bourdieu, Pierre, Alain Darbel, and Dominique Schnapper. 1991. The Love of Art. European Art Museums and Their Public. Oxford: Polity Press.

Bourdieu, Pierre. 1995. The Rules of Art. Genesis and Structure of the Literary Field. Stanford California: Stanford University Press.

Bourdieu, Pierre. 1996. Distinction. A Social Critique of the Judgement of Taste. Cambridge: Harvard University Press. Boylan, Patrick J. 2006. The Museum Profession. In A Companion to Museum Studies. Edited by Sharon Macdonald. Oxford: Blackwell Publishing, pp. 415-30.

Butler, Shelley Ruth. 2015. Reflexive Museology: Lost and Found. In The International Handbooks of Museum Studies: Museum Theory, 1st ed. Edited by Andrea Witcomb and Kelly Message. Chichester: Wiley/Blackwell, pp. 159-82.

Dana, John Cotton. 1917. The Gloom of the Museum. Woodstock. Vermont: The Elm Tree Press. 
Dierking, Lynn. 2002. The Role of Context in Children's Learning From Objects and Experience. In Perspectives on Object-Centered Learning in Museums. Edited by Scott G. Paris. London: Lawrence Erlbaum Associates, Publishers, pp. 3-18.

DiMaggio, Paul. 1986. Cultural Entrepreneurship in Nineteenth-Century Boston. In Nonprofit Enterprise in the Arts. Studies in Mission and Constraint. Edited by Paul DiMaggio. New York and Oxford: Oxford University Press, pp. 41-61.

Duncan, Carol, and Alan Wallach. 1980. The Universal Survey Museum. Oxford and New York: Blackwell Press. Duncan, Carol. 2006. Civilizing Rituals. Inside Public Art Museum. London and New York: Routledge.

Flick, Uwe. 2009. An Introduction to Qualitative Research, Fourth Edition Sage. London: Sage.

Fowle, Kate. 2007. Who cares? Understanding the Role of the Curator Today. In Cautionary Tales: Critical Curating. Edited by Steven Rand and Heather Kouris. New York: Apexart, pp. 10-19.

Hooper-Greenhill, Eilean. 2003. Museum and the Shaping of Knowledge. London and New York: Routledge.

Journal of Laws. 2018. Item 720, The Museum Act of 1996. Available online: http:/ / prawo.sejm.gov.pl/isap.nsf/ DocDetails.xsp?id=WDU20180000720 (accessed on 3 May 2018).

Karp, Ivan, and Steven D. Lavine, eds. 1991. Exhibiting Cultures: The Poetics and Politics of Museum Display. Washington and London: Smithsonian Institution.

Kowalczyk, Wiktor. 2010. Celebrować, zabawiać czy edukować? Po co społeczeństwu są dziś publiczne muzea? Muzealnictwo 51: 55-62.

Kreps, Christina. 2003. Curatorship as Social Practice. Curator 3: 311-23. [CrossRef]

Macdonald, Sharon. 2006. Expanding Museum Studies: An Introduction. In A Companion to Museum Studies. Edited by Sharon Macdonald. Oxford: Blackwell Publishing, pp. 1-12.

Marincola, Paula, ed. 2002. Curating Now: Imaginative Practice/Public Responsibility. Full Text. Philadelphia: Philadelphia Exhibitions Initiative.

McCall, Vikki, and Clive Gray. 2014. Museums and the "new museology": Theory, practice and organizational change. Museum Management and Curatorship 1: 19-35. [CrossRef]

Norton-Westbrook, Halona. 2015. The Pendulum Swing. Curatorial Theory Past and Present. In The International Handbooks of Museum Studies: Museum Practice, First Edition. Edited by Conal McCarthy. Chichester: Wiley/Blackwell, pp. 341-57.

Nieroba, Elżbieta. 2016. Pomiędzy Dobrem Wspólnym a Elitarnością. Wspótczesny Model Muzeum. Opole: Wydawnictwo Uniwersytetu Opolskiego.

Reichertz, Jo. 2004. Objective Hermeneutics and Hermeneutic Sociology of Knowledge. In A Companion to Qualitative Research. Edited by Uwe Flick, Ernst von Kardoff and Ines Steinke. London: Sage, pp. 290-95.

Santos dos, Paula A. 2008. Don't we all have problems? In Can We Make a Difference? Museums, Society and Development in North and South. Edited by Paul Voogt. Amsterdam: KIT Publishers, pp. 40-53.

Simon, Nina. 2010. The Participatory Museum. Santa Cruz. Available online: http://www.participatorymuseum. org/ (accessed on 4 March 2018).

Szelag, Marcin, ed. 2012. Edukacja muzealna w Polsce. Sytuacja, Kontekst, Perspektywy Rozwoju. Raport o Stanie Edukacji Muzealnej w Polsce. Warszawa: NIMOZ.

Szukalska-Kuś, Anna, Michał Niezabitowski, and Sławomir Szafrański. n.d. Muzea i Muzealnicy w Nowych Czasach. Program Stowarzyszenia Muzealników Polskich. Available online: http:/ / www.muzealnicy.org/ nasze-dzialania/category/3-dokumenty (accessed on 4 March 2018).

Urbaniak-Zając, Urszula. 2013a. Obiektywna hermeneutyka jako metodologia i metoda badań empirycznych. In Badania Jakościowe w Pedagogice. Edited by Urszula Urbaniak-Zając and Ewa Kos. Warszawa: Wydawnictwo Naukowe PWN, pp. 169-221.

Urbaniak-Zając, Urszula. 2013b. Obraz zawodu pedagoga kształtujący się u studentów kierunku pedagogika—Przykład zastosowania obiektywnej hermeneutyki. In Badania Jakościowe w Pedagogice. Edited by Urszula Urbaniak-Zając and Ewa Kos. Warszawa: Wydawnictwo Naukowe PWN, pp. 222-53.

Valéry, Paul. 2005. Problem muzeów. In Muzeum Sztuki. Antologia. Edited by Maria Popczyk. Kraków: Universitas, pp. 87-90.

Vergo, Peter. 2006. Introduction. In The New Museology. Edited by Peter Vergo. London: Reaktion Books, pp. 1-5. First published 1989. 
Weil, Stephen E. 2007. From Being about Something to Being for Somebody: The ongoing transformation of the American museum. In Museum Management and Marketing. Edited by Richard Sandell and Robert R. Janes. London and New York: Routledge, pp. 30-48.

Witcomb, Andrea. 2003. Re-Imagining the Museum. Beyond the Mausoleum. London and New York: Routledge.

Zolberg, Vera L. 1994. "An Elite Experience for Everyone": Art Museums, the Public, and Cultural Literacy. In Museum Culture. Histories, Discourses, Spectacles. Edited by Daniel J. Sherman and Irit Rogoff. Minneapolis and London: Routledge, pp. 49-65.

Zolberg, Vera L. 2004. Conflicting Visions in American Art Museums. In The Sociology of Art. A Reader. Edited by Jeremy Tanner. London and New York: Routledge, pp. 194-205.

2018 by the author. Licensee MDPI, Basel, Switzerland. This article is an open access article distributed under the terms and conditions of the Creative Commons Attribution (CC BY) license (http://creativecommons.org/licenses/by/4.0/). 